УДК 811.111-26.019

DOI https://doi.org/10.26661/2414-1135-2021-83-17

\title{
МЕТАФОРОТВОРЕННЯ І РЕЛІГІЙНА ЛЕКСИКА В ХУДОЖНІЙ ЛІТЕРАТУРІ УКРАЇНСЬКИХ ДІАСПОРЯН ХХ СТ.
}

\author{
Ковтун А. А. \\ доктор філологічних наук, дочент, \\ професор кафедри історії та культури украӥнської мови \\ Чернівецький національний університет імені Юрія Федьковича \\ вул. Коиюбинського, 2, Чернівиі, Україна \\ orcid.org/0000-0002-0690-3265 \\ a.kovtun@chnu.edu.ua
}

\begin{abstract}
Ключові слова: релігійна лексема, семантичне оновлення, семантичний (метафорний) дериват, метафора з релігійним компонентом, розгорнута метафора.
\end{abstract}

Особливості семантичного оновлення релігійної лексики у творах письменників української діаспори XX ст., яка, на відміну митців материкової України, мала змогу правдиво відтворювати життя українців та ставлення їх до Бога - це тема, яка до 90-х рр. минулого століття в Україні залишалася поза увагою вітчизняних науковців, тому нині $є$ вельми актуальною. Аналіз лексико-семантичних процесів, що супроводжують метафоротворення з участю найуживанішої релігійної лексики в указаному матеріалі, розкриває кілька специфічних ознак.

По-перше, коли є потреба акцентувати на постійній (не тимчасовій) подібності чого- або кого-небудь зі світської та сакральної сфер, частіше обирають метафоротворення (не порівняння). По-друге, у процесі метафоротворення поєднують різнокатегорійні найменування (конкретне й абстрактне, матеріальне й нематеріальне та ін.), що додає висловленням піднесеності, урочистості, святковості, ліризму. Однак кількісно переважає метафорне поєднання однокатегорійних слів (це здебільшого давні, уже закріплені в мові утворення), що, очевидно, є реалізацією наміру письменників спілкуватися з читачами звичними образами. При цьому кожне метафорне перенесення ознак з участю релігійної лексики $\epsilon$ експресивно-оцінним. По-третє, досліджувані метафорні деривати можуть виконувати функцію іронійної характеристики чого-небудь або кого-небудь, однак такі вживання превалюють у прямому мовленні художніх персонажів-безвірників, які можуть зневажливо, іноді iз сарказмом послуговуватися релігійною лексикою як енантіосемійними елементами. Водночас авторське мовлення виразно відображає збереження українцями релігійної коректності у вживанні сакральних мовних одиниць поза релігійною сферою. По-четверте, діаспоряни вибудовують креативні багатослівні метафорні конструкції, які завжди стилістично забарвлені відтінком урочистості й піднесеності, що притаманно сакральним текстам. Імпліцитність складних метафор віддзеркалює вишуканість авторської думки, інтелект, глибоке розуміння Божих настанов. Креативність діаспорян культивована їх мисленнєвою свободою та високим рівнем духовності. 


\title{
METAPHOR-MAKING AND RELIGIOUS VOCABULARY IN 20th CENTURY UKRAINIAN DIASPORA FICTION
}

\author{
Kovtun A. A. \\ Doctor of Philology, Associate Professor, \\ Professor at the Department of History and Culture of the Ukrainian Language, \\ Chernivtsi National University \\ Kotsyubynskyi str. 2, Chernivtsi, Ukraine \\ orcid.org/0000-0002-0690-3265 \\ a.kovtun@chnu.edu.ua
}

Key words: religious lexeme, semantic renewal, semantic (metaphoric) derivative, metaphor with a religious component, extended metaphor.
The article deals with peculiarities of the religious vocabulary semantic renewal in the works of 20th century Ukrainian diaspora writers who, unlike their mainland colleagues, could faithfully reflect Ukrainians' life and attitude to God. This topic, which did not arouse interest in Ukrainian academia in the 1990 s, is today highly relevant. The analysis of lexico-semantic processes that come with metaphor-making involving religious vocabulary most often used in the mentioned material identified some of their specific features.

Firstly, when there is a need to emphasize the permanent (not temporary) similarity of objects from the secular and sacred spheres, metaphor-making (not comparison) is more often favored. Secondly, in the process of metaphormaking, a combination of names of different categories (concrete and abstract, material and immaterial, etc.) is used, which adds sublimity, solemnity, festivity and lyricism to the utterances. However, quantitatively, metaphorical combinations of words that do not diverge categorically prevail (they are mostly old, already fixed in the language), which clearly is a realization of the writers' intention to communicate with their readers through images common to them. Thirdly, the investigated metaphorical derivatives can perform the function of ironic characterization of the object, but such uses are more typical of the direct speech of the godless characters, which may disparagingly, sometimes even sarcastically, utilize religious vocabulary as enantiosemic elements. Meanwhile, literary works distinctly reflect religious correctness that the Ukrainians maintain when using sacred linguistic units outside the religious domain. Fourthly, the diasporan writers build creative, more-than-one-word metaphoric constructions, always with undertones of triumph and sublimity preculiar to sacred texts. Implicitness of the complex metaphors reflects the sophistication of the authors' thoughts, their deep insight into God's decrees. The diasporan writers' creativity is nurtured by their freedom of thought and a high level of spirituality.
Постановка проблеми. Релігійна лексика, що ввійшла до загальновживаного фонду української мови, відображає споконвічну релігійність українців, пов'язану, зокрема, із християнством. Вивчення вербалізації релігійної діяльності українців нині є одним із пріоритетних у вітчизняному мовознавстві. В. Німчук, Н. Бабич, М. Скаб, П. Мацьків, Н. Піддубна, Н. Пуряєва, О. Мирончук, Ю. Осінчук, С. Бібла, І. Бочарова, І. Павлова, А. Куза, Т. Коць, 3. Куньч, О. Петришина, О. Ковтунець та ін. після проголошення незалежності України активно долучилися до наукових пошуків, здійснюваних у ХХ ст. переважно за кордоном нашої держави. Зацікавленість лексикою цієї тематичної групи є зрозумілою: слова, посталі в релігійній сфері, називають предмети і явища, що відтворюють найдавніші стереотипи мислення українців, спосіб тлумачення світу наших пращурів. Розширює указаний спектр дослідження і діяльність істориків мови, які вивчають ранні писемні пам'ятки. Ці дослідники також занурюються в релігійність українців, бо, як зауважив Я. Рудницький, «коли б мати такий магніт, що виявляє усі прояви релігії, й приложити його до української літератури, то вона б завалилася: після витягнення з неї усіх тем і мотивів, мало що́ б залишилося» [1, с. 823$]$.

Особливу увагу українських лінгвістів привертає функціонування релігійної лексики за межами релігійної сфери. Після 70-річного табуювання 
релігійності в Україні багато мовознавців (М. Скаб, Л. Шевченко, Н. Сологуб, Т. Вільчинська, М. Навальна, Ж. Колоїз, О. Тодор, С. Богдан, Н. Піддубна, Ю. Браїлко, А. Ковтун, О. Ципердюк, О. Решетняк, А. Сірант та ін.) мобілізувалося для вивчення взаємодії загальновживаних і вузькотематичних релігійних слів. Така взаємодія створює умови для формування багатозначності, тобто розвитку семантичної деривації. Н. Пуряєва, зокрема, спостерегла чимало цікавих особливостей семантичної адаптації релігійних термінів у загальнолітературному мовленні. Наприклад, щодо терміна образ у релігійному значенні «<..> під впливом розвинутої в семантиці загальновживаної лексеми образ «обличчя» [СУМ, V, 560-561] в значенні однойменного терміна відбувся такий зсув: «зображення священної особи (осіб)» $\rightarrow$ «зображення обличчя священної особи (осіб)». Таке звуження терміна образ стало результатом його народного переосмислення, основою для якого могла стати синтагматична сполучуваність 3 атрибутом» [2, с. 63-64].

Порівняльний аналіз релігійних лексем за 11-томним «Словником української мови» i пострадянськими словниками тлумачного типу, на думку I. Ренчки, ілюструє відхід сучасної лексикографії від принципів атеїстичного трактування лексем, «втрату ними негативного оцінного статусу, коли більшість проаналізованих тлумачень нейтральна або демонструє розвиток позитивного забарвлення лексем, що пов'язано зі зміною сприйняття та ставлення до релігії у суспільстві» [3, с. 13]. Із 1080 релігійних лексем, повернених після 1991 р. ХХ ст. до лексикографічного обігу, за підрахунками О. Ковтунець, більшість (837) є семантично оновленою [4]. Низка оновлених лексем - це образні похідні, сформовані поза релігійною сферою, значення яких, як і прямих, уже усталилися в суспільній практиці, мовці їх сприймають як самостійні. Цим переносні значення i відрізняються від переносного вживання слова, що використовується в мовленні як один із засобів надання висловленню певної образності й виразності [5, с. 33]. Вивчення семантичного потенціалу релігійної лексики, яку зафіксовано у творах українських письменників, табуйованих у ХX ст., вважаємо актуальним, оскільки воно сприяє відродженню цього потужного лексичного шару.

Мета статті - виявлення особливостей семантичного оновлення релігійної лексики у творах письменників української діаспори ХX ст., що відображають закономірні мовні явища, пов’язані 3 цією давньою за походженням лексикою, яка тривалий час через заборону залишилася поза увагою вітчизняних науковців. Вибір матеріалу дослідження мотивований тим, що в минулому столітті українські діаспоряни, на відміну від співвітчизників з материкової України, мали можливість брати участь у богослужіннях, без спотворення відтворюючи своє шанобливе ставлення до церкви.

Предмет дослідження - лексико-семантичні процеси, характерні для семантичної деривації релігійної лексики, залученої до нерелігійного мовлення.

Об'єкт дослідження - релігійні лексеми, легко впізнавані більшістю мовців як елементи християнської пресупозиції.

Виклад основного матеріалу дослідження. Зі зміною сфери використання спеціальні слова можуть зазнавати у мові таких самих змін, як звичайні слова, - розширювати, звужувати або змінювати свою семантику, входити до складу порівнянь, метафор, вживатися в переносному значенні, закріплювати за собою це значення [6, с. 64]. Одна 3 найприкметніших ознак мови письменників української діаспори - активне вживання релігійної лексики в образних значеннях. Автори частіше вдаються до метафоротворення, обираючи між метафорою i порівнянням, якщо їм важливо наголосити на постійній, а не тимчасовій подібності чого-небудь. Коли ж автори характеризують швидкоплинну ознаку, то вони конструюють переважно порівняльні звороти 3 релігійним компонентом, при цьому там він є об'єктом порівняння. Наприклад: 1) порівняння: Похилені лани пшенииі зводять спини, ніби ченці по довгій молитві (У. Самчук); Твоя далека пісня, як хорал (Є. Маланюк); Чиста, затишна, маленька хатина... з маленьким портретом Шевченка, щзо висів біля покуття, мовби образок, під королівськими рушниками... (І. Багряний); Позичені цуигарки були, як манна $з$ неба, й ичіла камера раювала, курячи жадібно кожен свою цчигарку... (I. Багряний); 2) метафора: Гадаю: так дивно, мабуть, з людством... тепер все в ньому перевернулось, мов з надрів духовної плянети життя його: вибухнуло, розбило тоненьку корочку, потріскану, нитками фарисейства зииту (В. Барка); <.. > переміг апокаліптичного вісника, ще символізує собою голод (В. Барка); Загорялась $і$ любов до брата, щзо його колись у дитинстві найбільше любив $і$ жалів, як раненого, як покинутиго на дорозі самаритянською любов'ю (У. Самчук); Чи знайшов щзастя той юнак з свойм янголомхоронителем, з тією дівчиною, невідомо (І. Багряний).

Прийнято шукати аналогію дальшого до ближчого, звичного до несподіваного, нового до вже відомого і тощо [7]. Діаспоряни, за нашими спостереженнями, залучають релігійні назви для позначення нерелігійних понять, поєднуючи різнокатегорійні найменування (конкретні й абстрактні, матеріальні й нематеріальні тощо), що додає 
висловленням піднесеності, урочистості, святковості, ліричності настрою художніх персонажів. Таке буває у разі висвітлення неординарних подій: Дай руку - ходім в мою душу, в мій храм (О. Олесь); Тільки часом - Твій єдиний готикПовстають жертовники топіль (С. Маланюк); Жертовник в сери̧і (В. Барка); За стінами природа: стосвічник до Царських воріт, завішених блакиттю (В. Барка); Троцькісти, дашники, сіоністи, сочіалісти... Ветерани револючії... Bci, всі сидите отуm - на «Голгофі Револючіï» (I. Багряний). Емоційно-піднесений стан людини (відчуття радості, задоволення, натхнення тощо, окреслене семантичним полем «емоція») називають, наприклад, храмом - назвою релігійної споруди (семантичне поле «будівля»): Розкинувсь по горбах сад; груші (білі!) палають. Синичка нікого не боїться - храм! забуто печалі й зітхання видужуй душею (В. Барка); В душі моїи храм Щодня тебе вгледжуя там (О. Олесь).

Для такого типу метафоротворення характерний антропоморфізм. Наприклад, В. Барка «олюднює» обіднє сонце через образ блискучого одягу священника: Соние, вдягнувшися в ризи, як свящзеник, дивиться в вічі. У. Самчук персоніфікує комунізм: I червоний, суворий бог не видержав. Зашироко розмахнувся... Не видержав скажений ідол (У. Самчук). Іноді виникає потреба уподібнити людську душу до тваринної, щоб, як у творі Н. Королеви, передати всю нікчемність людської натури за допомогою огидної миші: Душа в нього змаліла, під серцем так засмоктало тривогою, щуо та вбога душа мишею переляканою шуснула, немов з тіла вирватись була радніша (Н. Королева).

Однак під час формування похідних образних значень у релігійних лексемах все-таки кількісно переважає поєднання назв, які не розходяться категорійно (наприклад, обидва найменування $є$ назвами місць чи назвами істот, предметів, явищ та ін.): Це не тюрма, а просто рай (Барка), де i тюрма, і рай указують на місце; Мати Вірина відходила на село за харчами, Віра лишалась самою, поява Сашка була для неї збавленням, янголом-хоронителем (У. Самчук); Чи знайшов щуастя той юнак з своїм янголом-хоронителем, з тією дівчиною, невідомо (І. Багряний), де хлопецьь чи дівчина і янгол-хоронитель - назви істот. Ця особливість зближення однокатегорійних слів у процесі метафоротворення із залученням релігійних лексем, очевидно, $\epsilon$ реалізацією наміру письменників орієнтуватися на читача, для якого ближчі звичні образи, оскільки помічено, що однокатегорійні перенесення семантичних ознак - це здебільшого давні утворення, уже закріплені в мові. Наведемо кілька прикладів 3 реалізаціями релігійної лексеми сnовідb в усталених переносних значеннях:
Почула ци побачила шматок людського... Зрозуміло. Але разом иче була також сповідь. Тягар душі; У тієї язичок, і Марія не раз переслухала сповідь; Судді вимагали сповіді підсудних: хто вони, якого роду, звідки прийшли, чого прийшли? (iз творів У. Самчука).

Слід зазначити, що всі метафорні перенесення, референти яких перебувають у різних сферах (сакральній і світській), є експресивно-оцінними:Маріє! Висповідай мене. Даруй усе, щзо зробив тобі у дні молодості (У. Самчук) - висповідати «nерен. пробачити скоєні провини» (як у церкві на сповіді); ...до Віри потихеньку вступив Ганс та почав свій акафіст. Що вони, мовляв, думають? (У. Самчук) - aкафicm «перен., ірон. напучування» (як в акафісті); ...коли віск розтає, мачає у нього пензлика $і$ виводить по злегка підогрітому яйцю свої невибагливі, але чудові візерунки. Виводить «зірки», виводить «ключки», виводить «кривий поясо».... I при тому виглядає вона натхненно... Мама священнодійствує (У. Самчук) - священнодіяти «перен., уроч. виконувати яку-небудь справу особливо урочисто й поважно» (як церковний обряд). Із прийомів метафорного опису за допомогою релігійної лексики письменники продуктивно використовують гіперболу: Вартовий читає напружено «Капітал». Тре чоло стомлено. Шанобливо гортає сторінки, мріє: - Біблія Революиії!. (І. Багряний); Ти, Гнате! Ти свята людина (У. Самчук); А де ж тут твій старий?.. A мати? То значить, ти тут изар i Бог... (У. Самчук).

Виконання функції іронійної характеристики чого-небудь або дій, вчинків, поведінки кого-небудь - це ще одна риса, притаманна використанню метафорних значень у релігійних лексемах поза релігійною сферою у творах діаспорян XX ст. Однак ця риса властива, зокрема, прямому мовленню художніх героїв-безвірників, які зневажливо, іноді із сарказмом послуговуються релігійною лексикою. Її вони добре знають, але релігія, віра в Бога для них нічого не важать: До камери впихнули сивого, аж білого - сяючого білизною діда... - Маєте месію... (І. Багряний) - тут месія «перен., ірон.-зневажл. - рятівник». І. Муромцев називає подібну значеннєву поляризацію, виражену залежним від контексту переносним вживанням, живою енантіосемією [8, с. 143]. Діаспоряни використовують у своїх творах релігійні слова у ситуаціях, які зовсім не властиві для цього шару лексики, коли реалізовують намір створити якнайвищий рівень експресії під час вираження максимально негативної оцінки певних реалій життя чи явищ. На цей процес позитивно впливає семантична відстань між сакральним і профанним. Про таку іронійну образність можуть сигналізувати авторські графічні засоби: Так чомусь в иій країні нарід називає всіх робітників НКВД 
й мілічії «архангелами»! (I. Багряний); Удавати з себе «богочоловіка», «цуаря всесвіту» (І. Багряний); ...яке, справді, мінливе $i$ по-різному гарне обличчя!.. А сум «богині» був тепер дійсно щчирий (В. Винниченко). Поряд із цим матеріал дослідження послідовно відображає збережену українцями релігійність у вживанні сакральних мовних одиниць поза релігійною сферою.

Частина метафор, вибудувана на далекопериферійних семантичних компонентах, вимагає додаткових роз'яснень. Так, Н. Королева спочатку подає метафору ангельський чин (,перен. «чернечий»), а далі розгортає логіку цього переносного вживання: Стремів до монастирської гармонії й порядку, мріяв, будучи в чині ангельськім, побачити ангелів на власні очі, як бачили їх святі, люди духа.

Окрім однослівних метафор, розвинених від релігійних назв, діаспоряни продукують творення розгорнутих метафорних конструкцій, які завжди зберігають характерне для сакральних текстів стилістичне нашарування урочистості й піднесеності: На чистім престолі із сліз і із крові Курить моє серие, палає в любові (О. Олесь). У цьому непростому асоціативно-образному комплексі розкривають багатий семантичний ресурс релігійної лексеми престол два означення чистий та із сліз і із крові.

Нейтралізувати у тексті метафору означає «знищити три чверті насолоди у творі, що створена для поступового розгадування; навіяти його - ось мрія» [9, с. 84]. У разі заміни таких метафорних відрелігійних перифраз, як ковчег, щзо дав Христос, та скінія духовна, які використовує В. Барка, варіантами віра Христова чи Церква контекст би залишився без великої частини свого емотивного ресурсу: $A$ ми? Чи в сериях несем ковчег, щзо дав Христос: заповідь Його? Покинули! I понесли злобу. Без молитов, згорділи, щуо в нас родюча земля. От, відібрана. Без молитов згорділи, щзо багато хліба було. Віднявся. Бо з пирогами забули скінію духовну.

Складні метафори 3 релігійним компонентом можуть бути вибудвані без авторських натяків, щоб не заважати вільному сприйняттю тексту читачем: Грім на хмарі Біблію читає... Тополя пошепки: страшний який твій плач, Icaic! (В. Барка). Однак частіше вони містять ключові слова, підказки для розуміння авторського метафоротворення: Страждання - се стежка, яка веде на високі гори раювання, Тільки той, хто страждав, пізнав світ і поділив тугу його Твория (О. Олесь); Неоия ненною ризою доброти і смутку Божого накрито замучених (В. Барка); Здібні храмину тіла кожного з нас нищити, - сказав батюшка, - а душу вбити безсилі, бо вічна (В. Барка); Навколо хащуі й печеніги, / А в кельї- тиші ніжний спів, / Реторти, ичиркуль, колби, книги, / I Ви (до М. Рильського. - А. К.) - алхімік мудрих слів (С. Маланюк). Імпліцитні метафори упрозорюють вишуканість думки, концентрують інтелект авторів, спрямований спонукати читача до пошуку Божих істин, правди життя, екології духовних якостей: Між горбами річка, внизу двобаштний собор сіре видіння над дзеркалом, стрілками молитву тче; Думка - з нею до мудрости Твория йдемо; душами ростемо - тополями в сонці: хоч і ранені багристими гріхами восени; Кожному дано приступець існування, обмежений сонцевими тростинками. Келія під небосхилом (В. Барка). Мабуть, са́ме такі еліптичні метафори мала на увазі Н. Крюкова, зауважуючи: «<..> неможливо передати однією, навіть кількома фразами всю хитру павутину рефлективних перекидань i рефлективних мостиків, породжених метафоро» $[10$, с. 37].

Висновки і перспективи подальших досліджень. Аналіз семантичного оновлення найуживанішої релігійної лексики, віддзеркаленої в художній літературі українських діаспорян XX ст., доводить: 1) коли важливо наголосити на постійних (не тимчасових) подібностях чого- чи кого-небудь зі світської та сакральної сфер, письменники частіше обирають метафоротворення, а не порівняння; 2) у процесі метафоротворення письменники поєднують різнокатегорійні найменування (конкретні й абстрактні, матеріальні й нематеріальні та ін.), додаючи висловленням піднесеності, урочистості, святковості, ліризму, однак кількісно переважає метафорне поєднання одиниць, які не розходяться категорійно (са́ме таких дериватів закріплено в мові більше), що, очевидно, пов' язано з прагненням передати звичне мовлення українців; 3) метафорні похідні можуть виконувати функцію іронійної характеристики чого- або кого-небудь, але частіше вживаються у прямій мові персонажів-безвірників, які зневажливо, іноді із сарказмом послуговуються релігійними словами як енантіосемійними одиницями; 4) діаспоряни практикують продукування розгорнутих метафорних конструкцій 3 релігійним компонентом, що завжди зберігають характерне для сакральних текстів стилістичне нашарування урочистості й піднесеності та відображають глибину авторських міркувань про важливість Божих заповідей.

Перспективу подальшого дослідження вбачаємо в аналізі семантичних змін у релігійній лексиці, яку використовували українські діаспоряни в публіцистичній літературі XX ст. 


\section{ЛІТЕРАТУРА}

1. Рудницький Я. Вияви релігійності в українській совєтській літературі: 1953-1988. Спроба аналізу. Науковий конгрес до 1000-ліття Хрещення Руси-Украӥни : 3б. праць. Мюнхен, 1988. С. 823-846.

2. Пурясва Н.В. Формування української церковно-обрядової термінології (назви богослужбових предметів) : дис. ... канд. філол. наук : 10.02.02. Київ, 2001. 235 с.

3. Ренчка I. Ідеологізація та деідеологізація лексем у словниках української мови $\mathrm{XX}$ початку XXI століть : автореф. дис. ... канд. філол. наук : 10.02.01 «Українська мова»; Нац. ун-т «Києво-Могилянська академія». Київ, 2017. $20 \mathrm{c}$.

4. Ковтунець О.С. Актуалізація лексики української літературної мови кінця XX - початку XXI століття : автореф. дис. ... філол. наук : 10.02.01 «Українська мова»; Ін-т укр. мови НАНУ. Київ, 2017. 23 с.

5. Олійник І.С. Слово в лексичній системі української мови. Сучасна українська літературна мова. Лексика $і$ фразеологія / за заг. ред. І.К. Білодіда. Київ : Наукова думка, 1973. С. 27-100.

6. Непийвода Н.Ф. Про поняття «детермінологізація». Мовознавство. 1983. № 5. С. 64-67.

7. Тараненко O.O. Полісемічний паралелізм і явище семантичної аналогії. Київ : Наук. думка, 1980. 114 с.

8. Муромцев I.В. Енантіосемія як спосіб номінації в сучасній українській мові. Вибрані твори. Харків : Харк. істор.-філолог. тов-во, 2009. C. $128-151$.

9. Dittmann L. Stil, Structu. München, 1976. $350 \mathrm{~s}$.

10. Крюкова Н.Ф. Средства метафоризации и понимание текста. Тверь : Твер. гос. ун-т, 1999. $128 \mathrm{c}$.

\section{REFERENCES}

1. Rudnytskyi, Ya. (1988). Vyiavy relihiinosti v ukrainskii sovietskii literaturi: 1953-1988. Sproba analizu [Manifestations of piety in Ukrainian Soviet literature: 1953-1988. An attempt at analyzing]. Naukovyi konhres $u$
1000 littia Khreshchennia Rusy-Ukrainy : coll. of works (pp. 823-846). Munich.

2. Puriaieva, N.V. (2001). Formuvannia ukrainskoi tserkovno-obriadovoi terminolohii (nazvy bohosluzhbovykh predmetiv) [Formation of the Ukrainian ecclesiastical terminology (names of liturgical objects)]. Candidate's thesis. Kyiv : Institute of Ukrainian Language of the National Academy of Sciences of Ukraine.

3. Renchka, I. (2017). Ideolohizatsiia ta deideolohizatsiia leksem u slovnykakh ukrainskoi movy KhKh - pochatku KhKhI stolit [Ideologization and deideologization of lexemes in dictionaries of the Ukrainian language of the 20 th - early 21 st centuries]. Extended abstract of Doctor's thesis. Kyiv: National University of Kyiv-Mohyla Academy.

4. Kovtunets, O.S. (2017). Aktualizatsiia leksyky ukrainskoi literaturnoi movy kintsia KhKh pochatku KhKhI stolittia [Actualization of the vocabulary of Ukrainian literary language of the late 20th and early 21st century]. Extended abstract of Doctor's thesis. Kyiv : National Academy of Sciences of Ukraine Institute of Ukrainian Language.

5. Oliinyk, I.S. (1973). Slovo v leksychnii systemi ukrainskoi movy [Word in the Ukrainian lexical system]. Suchasna ukrainska literaturna mova. Leksyka $i$ frazeolohiia (pp. 27-100). Kyiv : Naukova Dumka.

6. Nepyivoda, N.F. (1983). Pro poniattia "determinolohizatsiia" [On the notion of determinologization]. Movoznavstvo, 5, 64-67.

7. Taranenko, O.O. (1980). Polisemichnyi paralelizm $i$ yavyshche semantychnoi analohii [Polysemic parallelism and the phenomenon of semantic analogy]. Kyiv : Naukova Dumka.

8. Muromtsev, I.V. (2009). Enantiosemiia yak sposib nominatsii $\mathrm{v}$ suchasnii ukrainskii movi [Enantiosemy as a way of nomination in modern Ukrainian.]. Vybrani tvory (pp. 128-151). Kharkiv : Kharkiv Historical-Philological Society.

9. Dittmann, L. (1976). Stil, Structu. München.

10. Krjukova, N.F. (1999). Sredstva metaforizacii $i$ ponimanie teksta [Means of metaphorisation and text comprehension]. Tver: Tver State University. 